\title{
Postnatal Dendritic Maturation of Alpha and Beta Ganglion Cells in Cat Retina
}

\author{
J. F. Dann, E. H. Buhl, and L. Peichl \\ Max-Planck-Institut für Hirnforschung, D-6000 Frankfurt 71, West Germany
}

\begin{abstract}
Of the 3 anatomically defined classes of ganglion cell in adult cat retina, the alpha and beta cells are the most well documented, thus providing a basis of comparison for developing ganglion cells. Alpha and beta ganglion cells in cat retinae at various ages from birth $(\mathrm{PO})$ to adult were intracellularly injected with Lucifer yellow. At all ages, both cell types strongly resembled their adult counterparts. However, transient developmental characteristics established their immaturity. These features included spiny protuberances and "rings" along the dendritic surface that were no longer detectable after 3 weeks of age. In a small proportion of both inner and outer stratifying alpha ganglion cells, there was aberrant dendritic arborization. However, by P5 there was no remaining evidence of this deviant stratification pattern and all alpha and beta cells displayed the adult pattern of unistratification (present among the majority of these cells from birth). For both alpha and beta cells, the area of greatest development was the retinal periphery. In this region alpha cell dendritic trees continued to grow until 3 weeks postnatally, when they approached the adult dendritic field size; around this time, the major period of beta cell dendritic expansion began. From birth to adulthood, the distance between alpha cell dendritic branching points increased, while the number of nodes and tips decreased with age. The temporal disparity between alpha and beta cell dendritic expansion suggests that postnatal dendritic development involves an active process of growth, rather than merely passive stretching.
\end{abstract}

In adult cat, retinal ganglion cells can be distinguished from one another by their anatomical and physiological properties. They can be grouped into at least 3 distinct anatomical classes: alpha, beta, and gamma (Boycott and Wässle, 1974), which correspond to the electrophysiologically determined $\mathrm{Y}, \mathrm{X}$, and $\mathrm{W}$ cells (Enroth-Cugell and Robson, 1966; Stone and Hoffmann, 1972; for reviews, see Levick, 1975; Levick and Thibos, 1983). These cell classes differ in dendritic field dimensions and branching patterns, as well as in cell body size (Boycott and Wässle, 1974).

\footnotetext{
Received May 28, 1987; revised Oct. 2, 1987; accepted Oct. 5, 1987.

We are indebted to Professor $\mathrm{H}$. Wässle for providing the facilities for this study and for invaluable discussions; to Professor B. Boycott, Dr. A. Rusoff, and Dr. M. F. Humphrey for constructive criticism of the manuscript; to F. Boij for support with illustrations; and to I. Odenthal for typing the manuscript. Special thanks to $H$. Ahmed for patience and skill in graphically reconstructing all of the cells in this study, in addition to further excellent technical assistance.

Correspondence should be addressed to Dr. J. F. Dann, Max-Planck-Institut für Hirnforschung Deutschordenstrasse 46, D-6000 Frankfurt/M. 71, FRG.

Copyright (C) 1988 Society for Neuroscience $0270-6474 / 88 / 051485-15 \$ 02.00 / 0$
}

Of these cell types, the alpha and beta cells are the bestdocumented in adult cat and therefore provide a firm comparative basis for a developmental study. Alpha cells have the largest cell body, of approximatcly $30 \mu \mathrm{m}$. The diametcr of the dendritic tree, which originates from 4-6 primary dendrites, ranges from $200 \mu \mathrm{m}$ centrally to approximately $1000 \mu \mathrm{m}$ in the retinal periphery (Wässle et al., 1981c). The cells project to the LGN, medial interlaminar nucleus (MIN), and superior colliculus (SC) (Kelly and Gilbert, 1975; Wässle and Illing, 1980; Illing and Wässle, 1981). Physiologically they correspond to the Y, or brisk-transient, cells (Cleland et al., 1975; Peichl and Wässle, 1981; Saito, 1983).

Beta cells have a compact bushy dendritic tree whose dendritic field ranges from $20 \mu \mathrm{m}$ centrally to $300 \mu \mathrm{m}$ in the periphery. They have a medium-sized cell body of approximately $20 \mu \mathrm{m}$, and at all retinal locations their dendritic fields are smaller than those of other ganglion cells (Boycott and Wässle, 1974). The major projection of beta cells is to the upper 2 layers of the LGN (Rodieck, 1979; Wässle et al., 1981a). Their physiological correlates are the $\mathrm{X}$, or brisk-sustained, cells (Levick, 1975; Saito, 1983).

Although the adult classification of these cell types may not apply in early prenatal development, at later stages cells begin separating into distinct phenotypes. Therefore, the present study was confined to postnatal analysis of alpha and beta cells to determine any changes in dendritic structure between birth and adulthood, and to relate such changes to overall retinal development.

By birth (P0), neurogenesis in the cat's retinal ganglion cell layer has ceased, although in peripheral retina cell proliferation continues in the inner and outer nuclear layers until 3 weeks of age (Johns et al., 1979). The period of ganglion cell death occurs between embryonic day 47 (E47) and birth, when there is an 8 -fold decrease in the number of cells within the ganglion cell layer (Stone et al., 1982). However, at 3 weeks of age, the surface area of the retina is still only about $65 \%$ that of the adult retinal area (Rusoff, 1979). Since continued postnatal retinal expansion cannot result from adjustment of cell numbers, it has been postulated (Rusoff, 1979; Mastronarde et al., 1984) that it must reflect growth and readjustment of the existing cells' processes.

Until recently (Ramoa et al., 1987), the only study that addressed the development of kitten retinal ganglion cell morphology involved Golgi staining of retinac from P21 to adult (Rusoff and Dubin, 1978; Rusoff, 1979; reviewed in Shatz and Sretavan, 1986). The small dendritic fields of beta cells stained quite successfully, revealing a central-to-peripheral gradient in dendritic field development. However, owing to technical limitations of the method, the larger dendritic fields of the alpha 

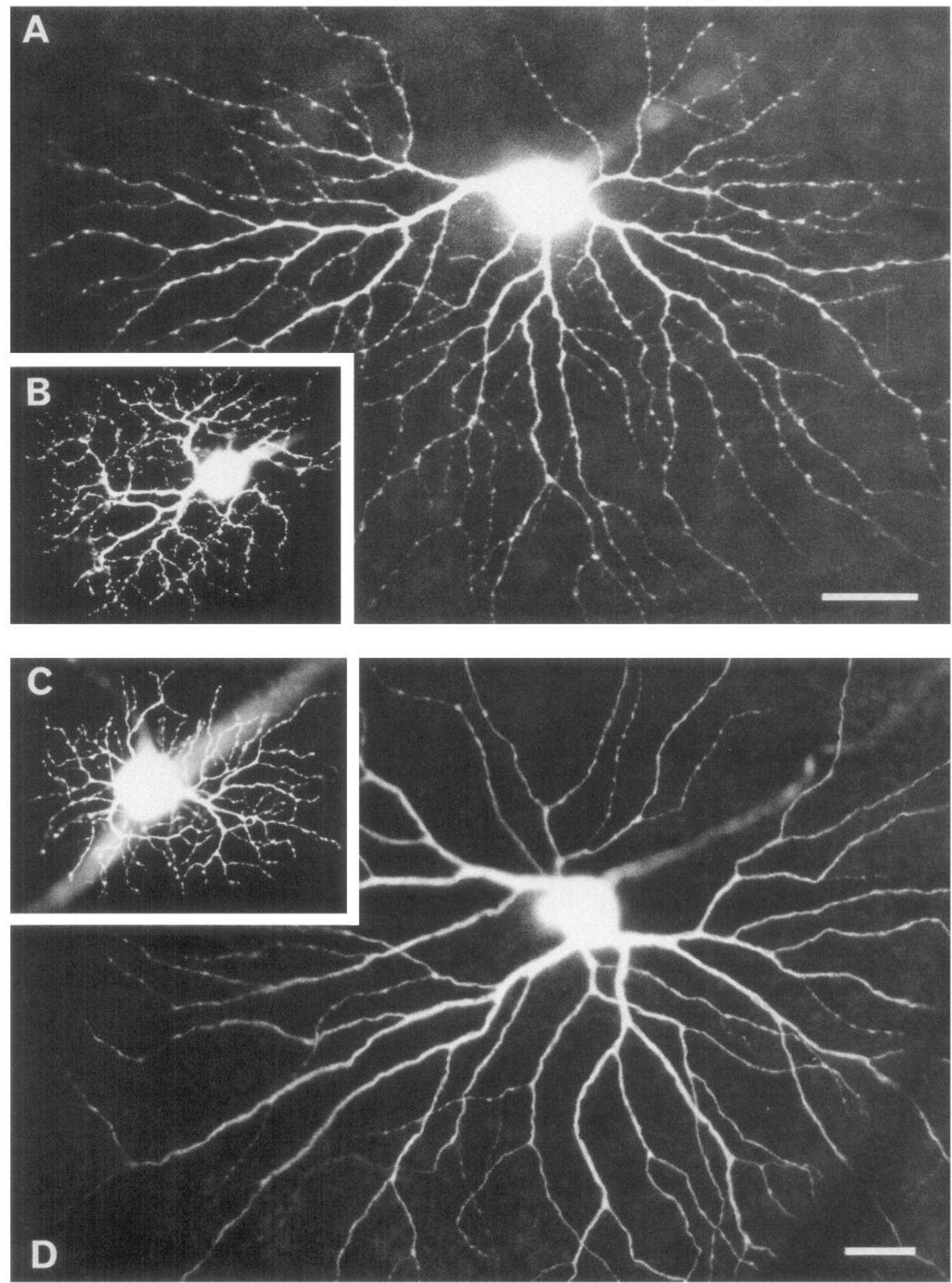

Figure 1. Lucifer yellow (LY)-filled ganglion cells from P0 retina $(A, B)$. The larger alpha cell $(A)$ contrasts with the small bushy beta cell $(B)$ Both cells are from peripheral retina and, despite their age disparity, look remarkably similar to the same class of adult cells ( $C$, beta; $D$, alpha). Scale bars, $50 \mu \mathrm{m}$. 
and gamma cells did not stain completely. A similar methodological restriction was found with HRP (Maslim et al., 1986). The recent availability of the intracellular injection technique of Tauchi and Masland (1984) provided a means with which to overcome these limitations and to analyze dendritic morphology in developing retinal ganglion cells. Qualitative and quantitative changes in the dendritic morphology of injected cells were analyzed, and also addressed was the question of whether territorial relationships between cells of the same functional class change during development. Preliminary results of cat ganglion cell development have been published (Dann et al., 1986, 1987).

\section{Materials and Methods}

A total of 18 domestic cats was used for intracellular injection of ganglion cells in fixed retinae. These included 4 animals from $4 \frac{1}{2}$ weeks of age to adult. Of the kitten retinae, 9 were investigated at postnatal day 0 (P0; birth), 2 at P5, and 3 at P13-P18.

All animals were anesthetized with Nembutal $(40 \mathrm{mg} / \mathrm{kg}$, i.p.). The eyes were removed under deep anesthesia and the animals then killed. A small incision was made in the eyeball posterior to the anterior chamber, and each eye was immersed in $4 \%$ paraformaldehyde in $0.1 \mathrm{~m}$ phosphate buffer $(\mathrm{PB})$ at $\mathrm{pH} 7.4$ for half an hour. Then the anterior chamber and lens were completely removed and the eyes fixed for a further $30 \mathrm{~min}$. This method of fixation ensured there were no folds in the kitten retinae.

After fixation, eyecups were transferred to $0.1 \mathrm{M} \mathrm{PB}(\mathrm{pH} 7.4)$ and were cut into 4 manageable sectors from which the neural retina was carefully dissected and the vitreous cut away. Division of the retina was such that one sector always contained the papilla, area centralis, and raphe region. This enabled comparison of equivalent retinal locations across individuals and age groups. Retinal pieces were floated onto a slide in $0.1 \mathrm{M} \mathrm{PB}$ ( $\mathrm{pH} 7.4$ ) and held in place by a fenestrated Millipore filter with an aperture slightly smaller than the retinal fragment. The slide was then placed into the injection chamber, which contained 2 mм ascorbic acid in 0.1 м PB (pH 7.4) (Tauchi and Masland, 1984), and the chamber transferred to a fixed-stage Zeiss ACM microscope.

Owing to the fragility of young kittens, collicular injections of Fast blue for retrograde labeling of retinal ganglion cells was not attempted. Instead, a few drops of the fluorescent dye DAPI (4',6-diamidino-2phenylindole), at a concentration of $10^{-7} \mathrm{M}$ in $0.1 \mathrm{M} \mathrm{PB}, \mathrm{pH} 7.4$, were placed on the retina in the injection chamber. It was then possible to locate alpha and beta cells by their soma size. Some cells stained more brightly within both cell classes, and it was found that these cells leaked when injected with Lucifer yellow (LY). Only the alpha and beta cells that appeared as faint images were injected successfully. Since this method of labeling cells with DAPI proved efficient, older retinae, including adult, were also stained by this means.

Thick-walled, glass capillaries (Clark Electromedical Instruments; 1.0 mm O.D. $\times 0.86 \mathrm{~mm}$ I.D.) were used to pull micropipettes with a DC resistance of approximately $90 \mathrm{M} \Omega$ in $0.1 \mathrm{M}$ PB (pH 7.4). These electrodes were filled with a $3 \%$ aqueous solution of LY (Stewart, 1981) and a platinum iridium wire was inserted. A Huxley-type micromanipulator was used to hold the electrode $30^{\circ}-40^{\circ}$ from the horizontal.

Neurons lightly labeled with DAPI were thus impaled by the advancing electrode, and LY was iontophoretically injected by a negative constant current of 1-3 nA for 1-5 min (Voigt, 1986), until bright fluorescence was apparent within terminal dendrites. Zeiss filters for LY (B.P. 400-440, FT 460, LP 470) and long-distance objectives (Zeiss Plan 2.5/0.08; UD 20/0.57; UD 40/0.65) facilitated intracellular staining under visually controlled epifluorescence. Up to 100 cells could be successfully filled in the same retinal portion over a period of several hours. A cell was considered completely filled if bright fluorescence extended to the terminal dendrites. Cells were excluded from analysis if LY diffused from the dendrites or soma during injection. Ganglion cells were readily identified by their LY-filled axon in the optic nerve fiber layer. Consequently the introduction of nonganglion cells into the analysis was excluded. After intracellular filling, retinae were mounted in glycerine and coverslipped for microscopic analysis.

The location of filled ganglion cells was carefully documented on maps drawn from the mounted retinal pieces. These maps were used to determine a cell's eccentricity (distance from the area centralis, the region
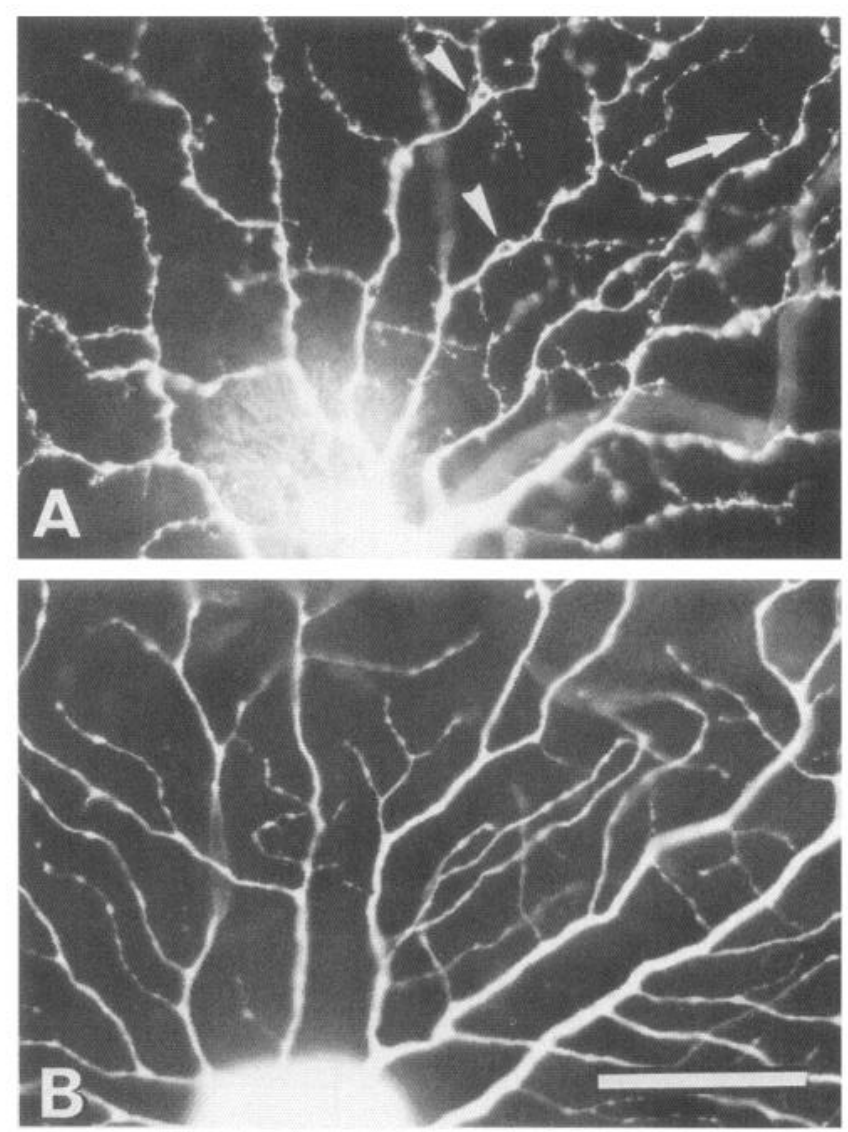

Figure 2. Despite their overall similarity in morphology, spiny protuberances (arrow) along their dendritic length demonstrated the immaturity of P0 ganglion cells, such as the alpha cell in $A$. Lacunae or dendritic "rings" (arrowheads) were another identifying feature of early postnatal retinal ganglion cells. These features became less prevalent by 3 weeks of age and were not present on adult cells, as illustrated by the dendrites of the adult alpha cell $(B)$. Scale, $50 \mu \mathrm{m}$.

of peak ganglion cell density) and to estimate the amount of shrinkage occurring during mounting. Linear shrinkage ranged between zero and $10 \%$. Photographic montages of intracellularly filled cells were obtained with black and white film and Zeiss Neofluar objectives. The cells were then graphically reconstructed from projected negatives. A semiautomatic image-analyzing system (Leitz A.S.M.) was used to measure soma and dendritic field sizes from magnified outlines.

To determine alpha cell dendritic coverage, dendritic field area was measured from the LY material. The density of alpha cells in both kitten and adult retinae was obtained from reduced silver-stained retinae processed according to the protocol of Boycott and Peichl (in appendix to Peichl and Wässle, 1981). In addition to the results from LY-filled retinae, coverage data were obtained from $3 \mathrm{P} 0,2 \mathrm{P} 5$, and $3 \mathrm{P} 14$ reducedsilver or Nissl-stained kitten retinae, 4 adult retinae, and from adult data published in Wässle et al. (1981c).

\section{Results}

\section{Morphology of developing alpha and beta cells}

In kitten retina, the ganglion cell classifications alpha, beta, and gamma, that have been used to describe the retinal ganglion cell population in adult cat (Boycott and Wässle, 1974) were applicable from $\mathrm{P} 0$, when cells could be unambiguously identified by intracellular injection of LY (Fig. 1). While the present study concentrated on the development of alpha and beta cells, occasionally gamma cells were impaled by the injecting electrode and filled with LY for comparison with the other cell classes. 


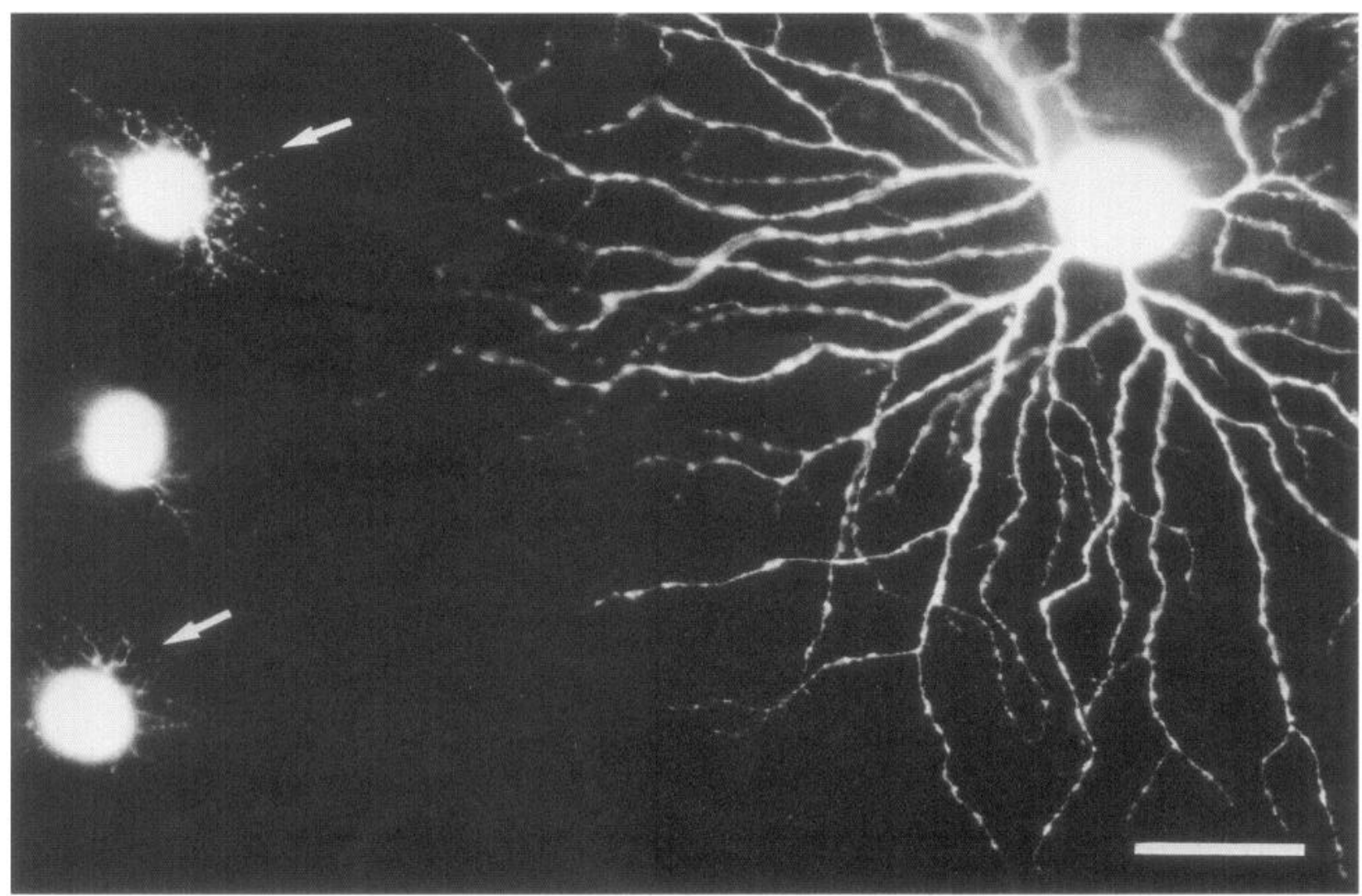

Figure 3. Lucifer yellow-filled alpha cell adjacent to $3 \mathrm{LY}$-filled beta cells from a P18 kitten. The dendrites of the upper and lower (arrowed) beta cells stratified within the "on" sublamina of the IPL and thus are in focus with the "on" alpha cell. Dendrites of the middle beta cell are out of the plane of focus, since they stratified in the "off" sublamina. Scale, $50 \mu \mathrm{m}$.

Despite the similarity in overall morphology to that of their adult counterparts (Figs. 1, 8, 9), alpha and beta cells in early postnatal retinae had distinct immature features. At all retinal eccentricities, spiny appendages were found on the dendrites of both cell classes. These appendages, which ranged from 1 to 10 $\mu \mathrm{m}$ in length, were present on the main dendrites and side branches (Fig. 2). They became less common by P5 and were absent by P18 (Fig. 3). Concomitantly, the dendrites began to transform from very delicate branches into more robust structures, appearing to thicken with continued development.

Another characteristic of kitten retinal ganglion cells was the presence of "rings" along the dendrites (Fig. 2). Unlike the spines, these dendritic "rings" were not found frequently, and were concentrated in the retinal periphery. They were present on the dendrites of alpha and beta cells, and in both classes were always confined to retinae less than 3 weeks of age. Neither spiny protrusions nor dendritic "rings" were ever found on adult ganglion cells.

In P0 retinae, an occasional structure was observed that resembled a growth cone. These were found very rarely at random locations within the peripheral retina, and were only observed on beta cells. This finding may reflect the delayed postnatal dendritic growth of beta, compared to alpha, cells.

\section{Stratification patterns}

Physiologically, the concentrically organized receptive fields of adult retinal ganglion cells can be separated into on-center and off-center units that respond to the respective "onset" or "offset" of a light response flashed onto their receptive-field centers. Anatomically, these cells have different patterns of stratification (Nelson et al., 1978; Peichl and Wässle, 1981). The "off'-ganglion cells have dendrites stratified within the outermost part of the inner plexiform layer (IPL). "On"-ganglion cells stratify in a layer of the IPL located nearer the ganglion cell layer. In kitten retinae from $\mathrm{P} 0$, this basic pattern of unistratification within the IPL had already been established for the majority of cells. As demonstrated by the pairs of adjacent cells in Figure 4, the cell in focus in the left micrograph of each pair (Fig. 4, $A, C)$ had dendrites stratified within the inner layer of the IPL, and is therefore an "on"-alpha (Fig. 4A) or "on"-beta (Fig. $4 C$ ) cell. Conversely, the cell in focus in the right micrograph of each pair (Fig. 4, $B, D$ ) is an "off'-ganglion cell. While the majority of alpha cells conformed to this basic pattern of unistratification from $\mathrm{P} 0$, there were exceptions. In a small number of cells, a few dendrites branched in the inappropriate sublamina of the IPL (Fig. 5). These deviating processes occurred on both inner and outer branching alpha cells. The frequency of cells that displayed some degree of bistratification began to diminish by P5. After P13-P15 all cells had achieved the adult pattern of unistratification.

The dense branching pattern of beta cell dendrites made it difficult to assess whether these cells contained dendritic aberrations similar to those of alpha cells. A fine deviating dendrite might have remained undetected, while the majority of dendrites could be localized within the same plane of focus, as demonstrated by the "on" and "off" pairs of cells in Figure 4. 

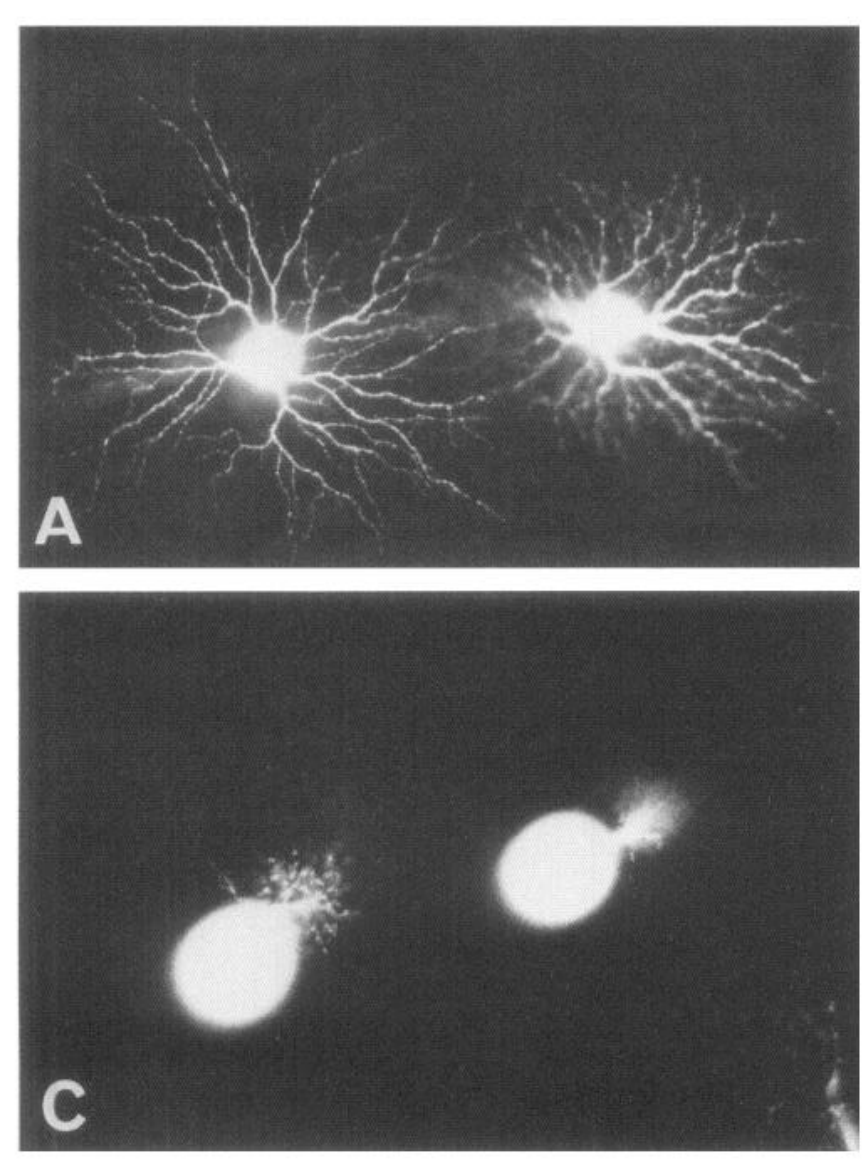
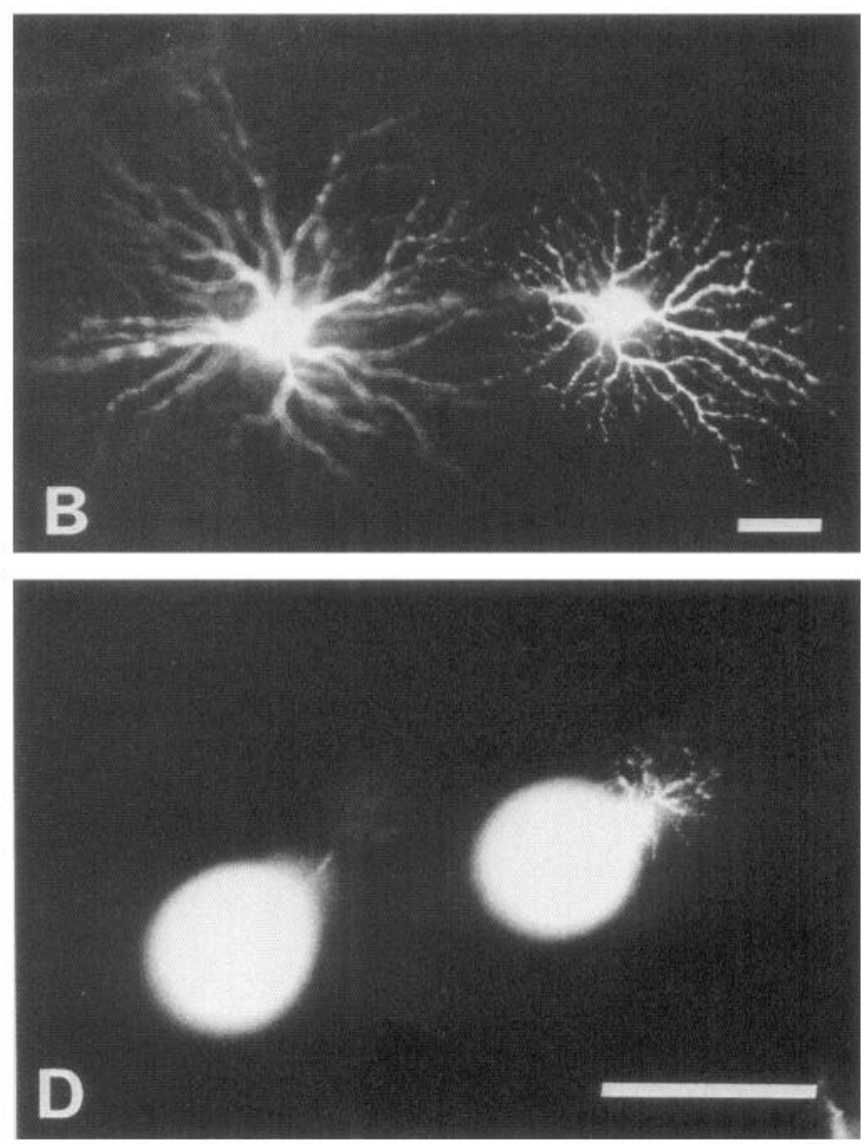

Figure 4. For both alpha and beta cells, the "on" and "off" pattern of dendritic stratification was present from P0. As clearly indicated by the alpha $(A, B)$ and beta $(C, D)$ cell pairs, when the "on" cells are in focus $(A, C)$ the "off" cell dendrites are completely out of focus. The converse applies when the "off" cells are in focus $(B, D)$. Scale bars, $50 \mu \mathrm{m}$.

\section{Quantitative aspects of development}

Dendritic branching pattern. The dendritic branching pattern was established for alpha cells by counting the number of nodes and tips. In accordance with Percheron (1979), nodes were defined as the point at which dendrites "branch" or "bifurcate" and tips as the "endpoint" of a dendrite. In the case of P0 dendrites, care was taken to avoid inclusion of the transient spiny protrusions during this quantification. Therefore, a node was only recorded if a definite dendrite of at least $14 \mu \mathrm{m}$ had formed. In general, spiny protrusions were finer than dendrites and easily distinguishable. In both newborn and adult alpha cells, the number of nodes and tips increased with increasing distance from the area centralis, except in the far periphery (Fig. $6, A, B)$. While there was some variation in the numbers within each stage, at all eccentricities P0 dendrites always branched more frequently than those of adults. Simultaneously, the distance between the branching points, or nodal distance, increased (Fig. 7, $A, B$ ). Therefore while the actual distance between dendritic nodes increased and the area of the dendritic tree expanded, some remodeling of the dendritic structure must have occurred.

Increasing soma and dendritic field size. Adult alpha and beta soma and dendritic field size increase with increasing distance from the area centralis (Boycott and Wässle, 1974). Consequently, central cells are smaller and more densely branched than are peripheral cells of the same class. Therefore, a centrally located alpha cell bears some resemblance to a peripheral beta cell in terms of dendritic tree size and morphology, but at equivalent retinal locations, the 2 classes are readily discernible by the quantitative and qualitative difference in their respective dendritic tree structure. This dependence of morphological properties on retinal eccentricity was observed from $\mathrm{P} 0$, when the central-to-peripheral gradient of dendritic field size had already been established (Figs. 8, 9), although the retina was still expanding and the morphology of alpha and beta cells was still immature. In the present quantitative analysis, eccentricity was an important parameter. Although it was impossible to directly compare locations on P0 and adult retinae (Mastronarde et al., 1984), it was possible to establish relative reference points in retinae from different stages. The area centralis was the reference point for identification of equivalent retinal locations. From this point a sampling line extended along the raphe towards the temporal periphery. In Figures 10 and 11, the abscissas show the distance from the area centralis, or eccentricity, along that sampling line.

Alpha cell development. From P0, the soma area of alpha cells gradually increased in both central and peripheral retinae. Cells closest to the area centralis $(0-0.5 \mathrm{~mm})$ had an average soma area of $254 \pm 72 \mu \mathrm{m}^{2} \mathrm{SD}$ (corresponding to a mean diameter of $18 \mu \mathrm{m}$ ) at P0. By P13-P15 the soma area in this region had increased to $326 \pm 131 \mu \mathrm{m}^{2} \mathrm{SD}$ (mean diameter, $20 \mu \mathrm{m}$ ) and there was a further slight increase until the adult mean soma area of $398 \pm 78 \mu \mathrm{m} \mathrm{SD}$ (mean diameter, $23 \mu \mathrm{m}$ ) was reached. 

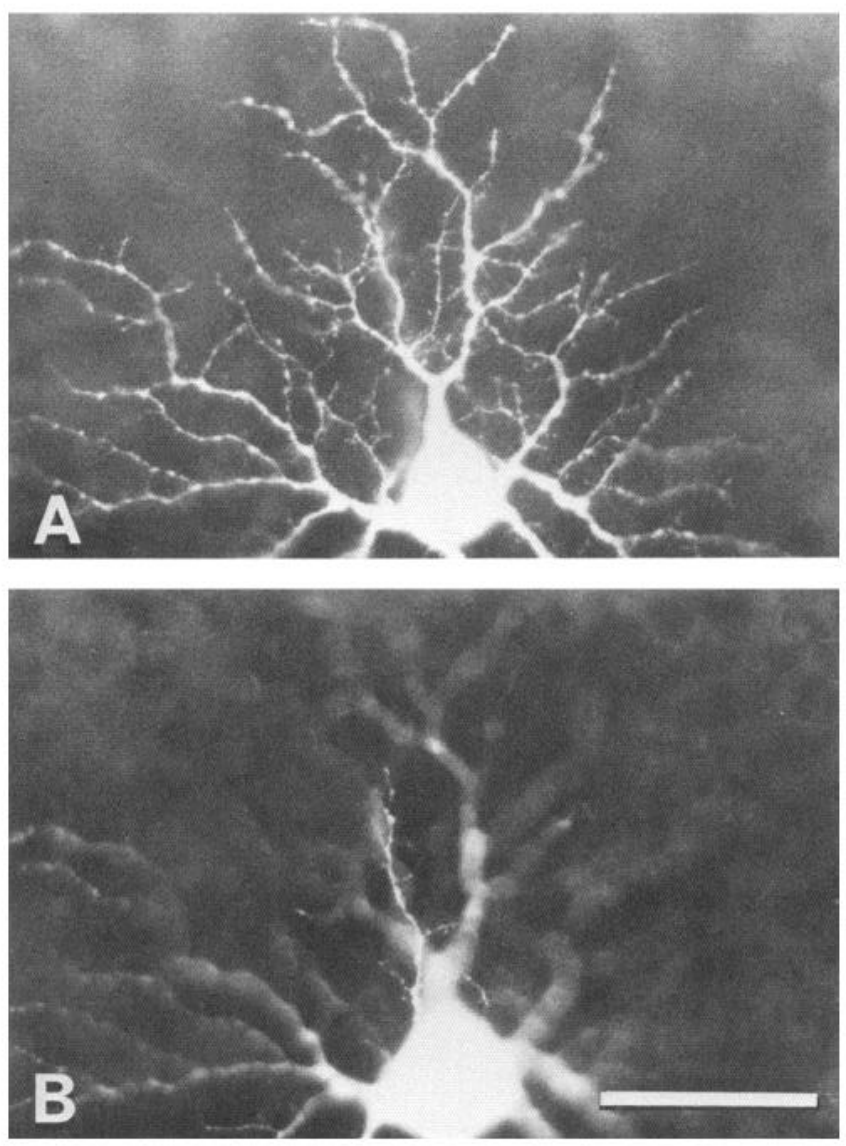

Figure 5. Most alpha and beta cells had their adult pattern of unistratification by P0. However, some alpha cells displayed a small degree of bistratification. Although the majority of their dendrites were unistratified $(A)$, the remaining dendrites branched in an inappropriate sublamina of the IPL $(B)$. Scale, $50 \mu \mathrm{m}$.

This increase in soma size in central retina was small compared to the dramatic increase in the soma size of peripheral alpha cells. From P0, at an eccentricity of $4 \mathrm{~mm}$, soma area rose from $325 \pm 77 \mu \mathrm{m}^{2} \mathrm{SD}$ (mean diameter, $20 \mu \mathrm{m}$ ) to an average of $640 \pm 87 \mu \mathrm{m}^{2} \mathrm{SD}$ (mean diameter, $29 \mu \mathrm{m}$ ) by P13$\mathrm{P} 15$. There was continued expansion of soma area in peripheral alpha cells up to the average adult size of $860 \pm 89 \mu \mathrm{m}^{2} \mathrm{SD}$ (mean diameter, $33 \mu \mathrm{m}$ ) was reached.

Changes in alpha cell dendritic field size are also illustrated in Figure 10. In the immediate vicinity of the area centralis, the dendritic field area of alpha cells was generally invariant during postnatal development. However, from an eccentricity of $2 \mathrm{~mm}$, increases in dendritic field area became apparent. At $2 \mathrm{~mm}$, the dendritic field area measured $0.09 \pm 0.05 \mathrm{~mm}^{2} \mathrm{SD}$ (mean diameter, $393 \mu \mathrm{m}$ ) at P0, and gradually increased throughout development until the adult area of $0.20 \pm 0.06 \mathrm{~mm}^{2} \mathrm{SD}$ (mean diameter, $564 \mu \mathrm{m}$ ) was achieved.

Similar to the increase in soma area, expansion of the dendritic field area during development was greatest in peripheral retina. As illustrated in Figure 10, at an eccentricity of $6 \mathrm{~mm}$ there was a 3-fold increase in dendritic field area from birth to adulthood.

Beta cell development. The pattern of increasing soma and dendritic field size for beta cells was different from that of the alpha cells. As illustrated in Figure 11, in central retina there was no increase in the size of beta cell somas with increasing age. At $\mathrm{P} 0$, close to the area centralis the average soma area measured $116 \pm 29 \mu \mathrm{m}^{2} \mathrm{SD}$ (mean diameter, $12 \mu \mathrm{m}$ ). Therefore central beta cells had attained their adult soma area proportions by birth. By contrast, peripheral cells continued to increase in soma area, ranging from the P0 figure of $162 \mu \mathrm{m}^{2}(\mathrm{SD}, \pm 21$ $\mu \mathrm{m}^{2}$; mean diameter, $14 \mu \mathrm{m}$ ), at an eccentricity of $5 \mathrm{~mm}$, to 234 $\mu \mathrm{m}^{2}$ (SD, $\pm 57 \mu \mathrm{m}^{2}$; mean diameter, $17 \mu \mathrm{m}$ ) by P13-P15. At a similar eccentricity in the adult, beta soma area measured 421 $\mu \mathrm{m}^{2}$ (SD, $\pm 97 \mu \mathrm{m}^{2}$; mean diameter, $23 \mu \mathrm{m}$ ).

From birth to adulthood (Fig. 11), for beta cells near the area centralis the average dendritic field area remained invariant at $0.002 \pm 0.0005 \mathrm{~mm}^{2} \mathrm{SD}$ (mean diameter, $55 \mu \mathrm{m}$ ), thus paralleling the constancy in soma size. However, at an eccentricity of $6.5-7.5 \mathrm{~mm}$, there was a gradual increase in dendritic field area, from $0.02 \pm 0.008 \mathrm{~mm}^{2} \mathrm{SD}$ (mean diameter, $200 \mu \mathrm{m}$ ) at P13-P15 to the average adult value of $0.06 \pm 0.02 \mathrm{~mm}^{2} \mathrm{SD}$ (mean diameter, $338 \mu \mathrm{m}$ ), that is, by a factor of 3 .

Alpha cell distribution. For P0, P13-P15, and adult retinae, alpha cell density was measured from center to temporal periphery across an area encompassing the raphe. In reduced-silver preparations of newborn kitten retinae (Fig. 12), the density ranged from 160 cells $/ \mathrm{mm}^{2}$ in the area centralis to $25-27$ cells/ $\mathrm{mm}^{2}$ in peripheral retina. At P15 density ranged from 170 cells/ $\mathrm{mm}^{2}$ in the area centralis to 20 cells $/ \mathrm{mm}^{2}$ in the periphery. Alpha cell density in the adult ranged from 165 cells $/ \mathrm{mm}^{2}$ centrally to 8 cells $/ \mathrm{mm}^{2}$ in the periphery (Fig. 13).

For P0, P13-P15, and adult, alpha cell coverage was calculated as the product of cell density and dendritic field area. Both $\mathrm{P} 0$ and P13-P15 coverage was calculated from the dendritic fields of LY-filled cells, since a large sample of well-stained dendritic fields of kitten cells was not available from the silver data. Adult coverage was calculated from both LY and reducedsilver data. As shown in Figure 13, there was some variation in dendritic field area, which appeared to be independent of staining method since the data did not show a consistent trend for either to exceed the other in size of dendritic field. Therefore, the apparent increase in dendritic field area, and consequent increase in coverage, at P13-P15 cannot result merely from the LY technique's being superior in revealing the full extent of dendritic field area since, in the adult, although the shape of the LY distribution resembles the P13-P15 graph and generally exceeds that of the silver-stained cells from mid-peripheral retina, there is still a decrease in coverage. The converse applies to the area centralis, where the distribution of silver-stained adult dendritic field areas resembles that of the P13-P15 data obtained from LY-injected cells.

Near the area centralis, average dendritic coverage ranged from 5 at P0 to 5-8 at P13-P15, then decreased to 3 in the adult, while at $3 \mathrm{~mm}$ the values were $4,8.5$, and 8 , respectively. Further peripherally $(6 \mathrm{~mm})$ the coverage at $\mathrm{P} 0$ remained around 4 , but increased to 9 at P13-P15, decreasing to nearly 6 in the adult. This increase in dendritic coverage at P13-P15 coincides with the time when alpha cells approach their adult dimensions, while the surface area of the retina is still only $65 \%$ that of the adult retina (Rusoff, 1979). There is a general trend in the coverage graphs of Figure 13 toward an increase in dendritic overlap between $\mathrm{P} 0$ and P15, followed by a peripheral decrease in overlap during continued retinal growth to adulthood.

Interpretation of these data must include the considerable variation in dendritic field sizes, and thus coverage values, at any eccentricity. For a more detailed analysis of coverage changes, 

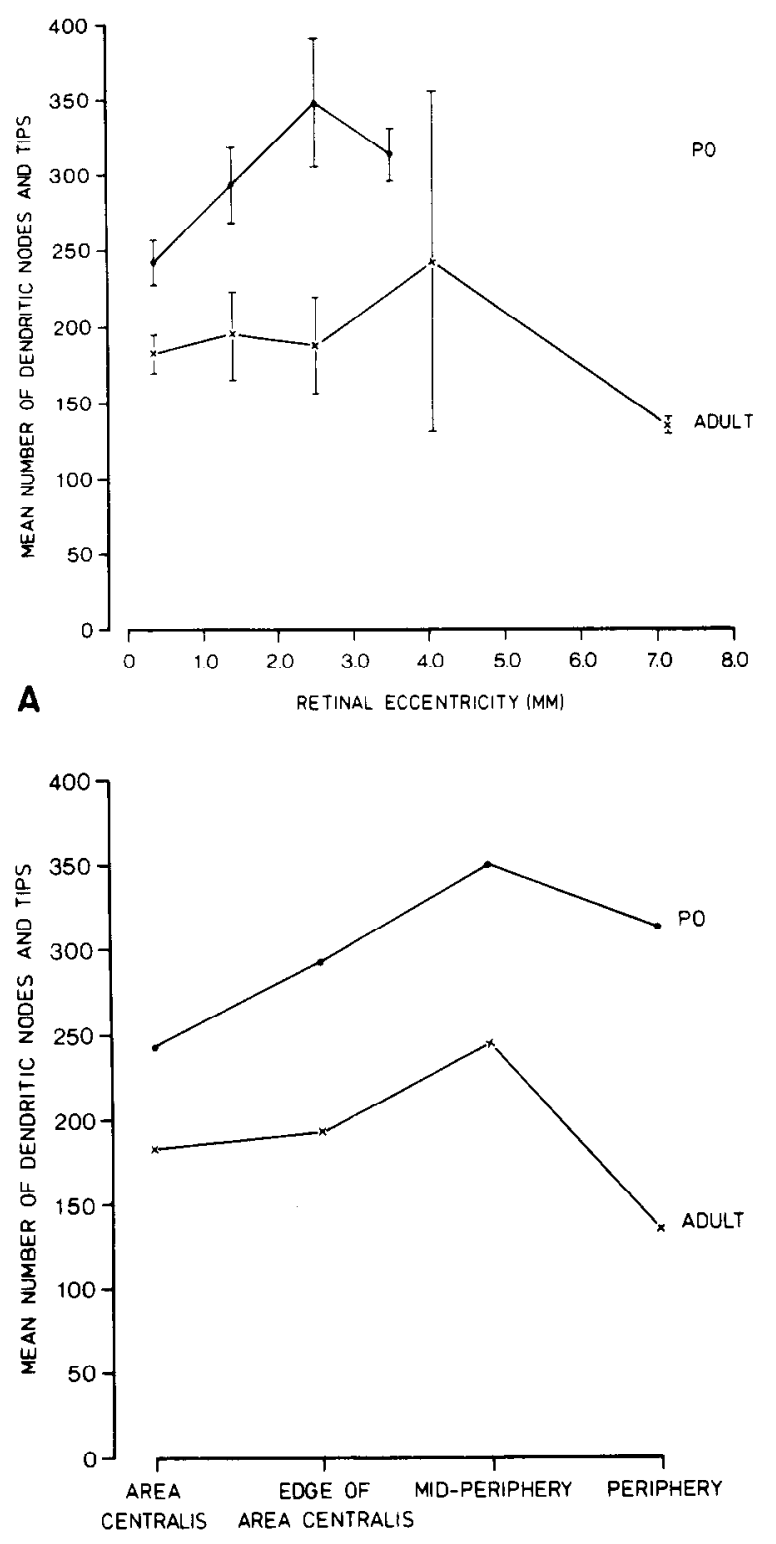

B

RETINAL ECCENTRICITY

Figure 6. $A$, The average number of dendritic nodes and tips (Percheron, 1979) for P0 and adult alpha cells was plotted against retinal eccentricity, that is, the distance of a cell from the area centralis. There was considerable variation at some points (for example, adult $4.0 \mathrm{~mm}$ ), as evidenced by the standard error bars ( $\pm 1 \mathrm{SE}$ ). Some variation may result from small samples at some eccentricities. Since corresponding retinal points change eccentricity during growth (Mastronarde et al., 1984 ), in $B$ nodes and tips were plotted against relative eccentricity to allow a more direct comparison between equivalent locations in $\mathrm{P} 0$ and adult retinae. The number of nodes and tips in $\mathrm{PO}$ always exceeded those of the adult and, at both ages, the numbers increased toward the retinal periphery, decreasing again at the most peripheral edge.

it is necessary to know the density distribution and dendritic fields for individual ganglion cell subclasses, because territorial interaction between neighbors seems to determine the coverage (Wässle and Riemann, 1978; Wässle et al., 1981b).

\section{Discussion}

\section{Temporal patterns of growth}

The cat retina, in terms of developmental events, matures earlier at the central area than at the periphery. The earliest-generated
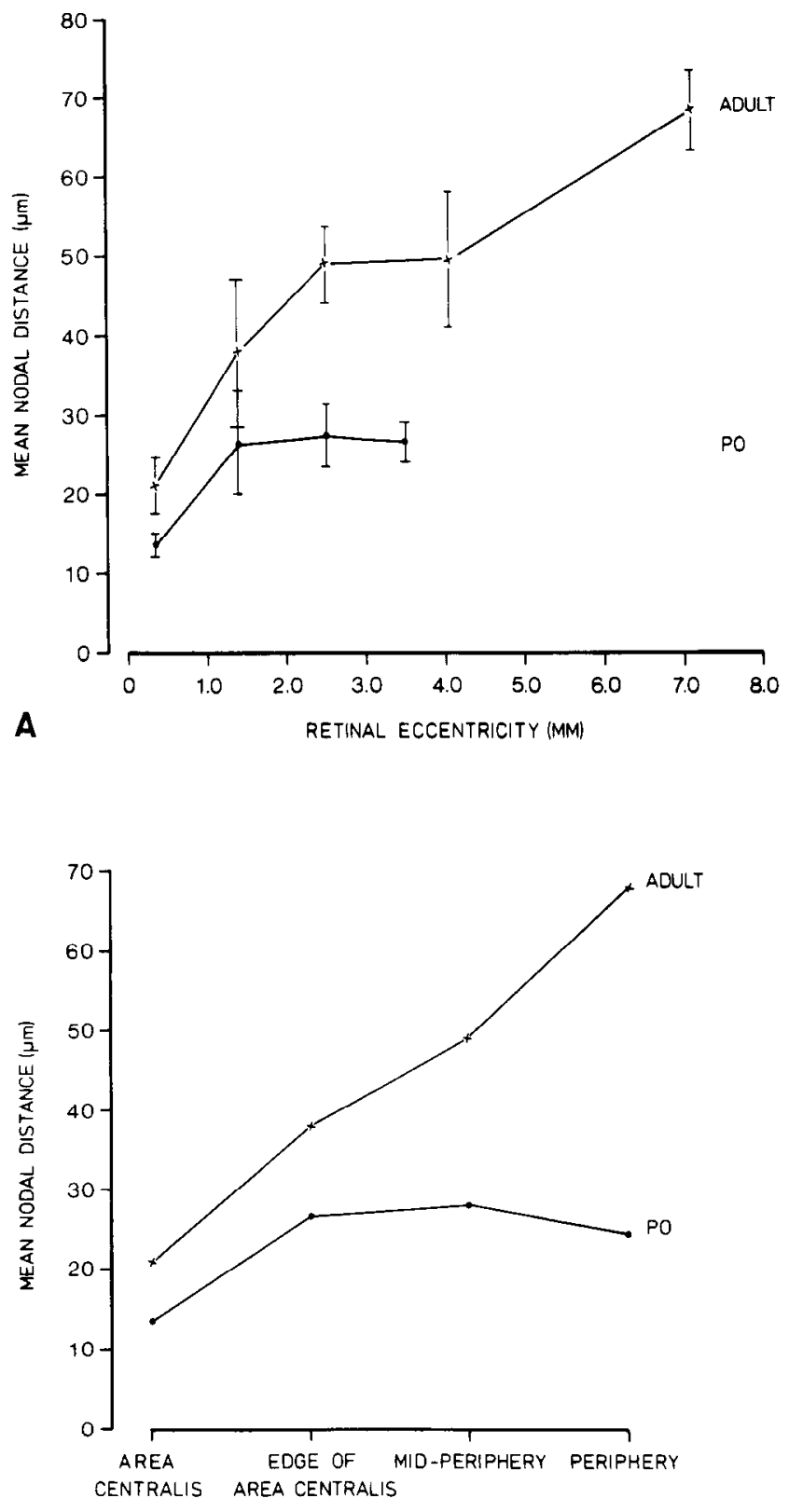

B RETINAL ECCENTRICITY

Figure 7. The average distance between $\mathrm{P} 0$ and adult alpha cell dendritic nodes was plotted as a function of retinal eccentricity $(A)$ and as a function of relative eccentricity $(B)$. In both $\mathrm{P} 0$ and adult dendrites there was a tendency for the distance between nodes to increase more in cells located in the retinal periphery. In contrast to the number of branching points (Fig. $6, A, B$ ), the nodal distance was greater in adults than at $\mathbf{P O}$.

cells lie near the central region (Walsh and Polley, 1985) and neurogenesis ceases first in this part of the retina, while the periphery remains an active proliferative zone (Johns et al., 1979; Rapaport and Stone, 1983) until 3 weeks after birth. Consistent with these findings, postnatal growth in the area centralis results in only a $3 \%$ increase in retinal area, while the periphery incrcases by about $80 \%$ between 3 postnatal weeks and adulthood (Mastronarde et al., 1984).

The present results indicate that the same central-to-peripheral gradient applies to retinal ganglion cell development. Cen- 


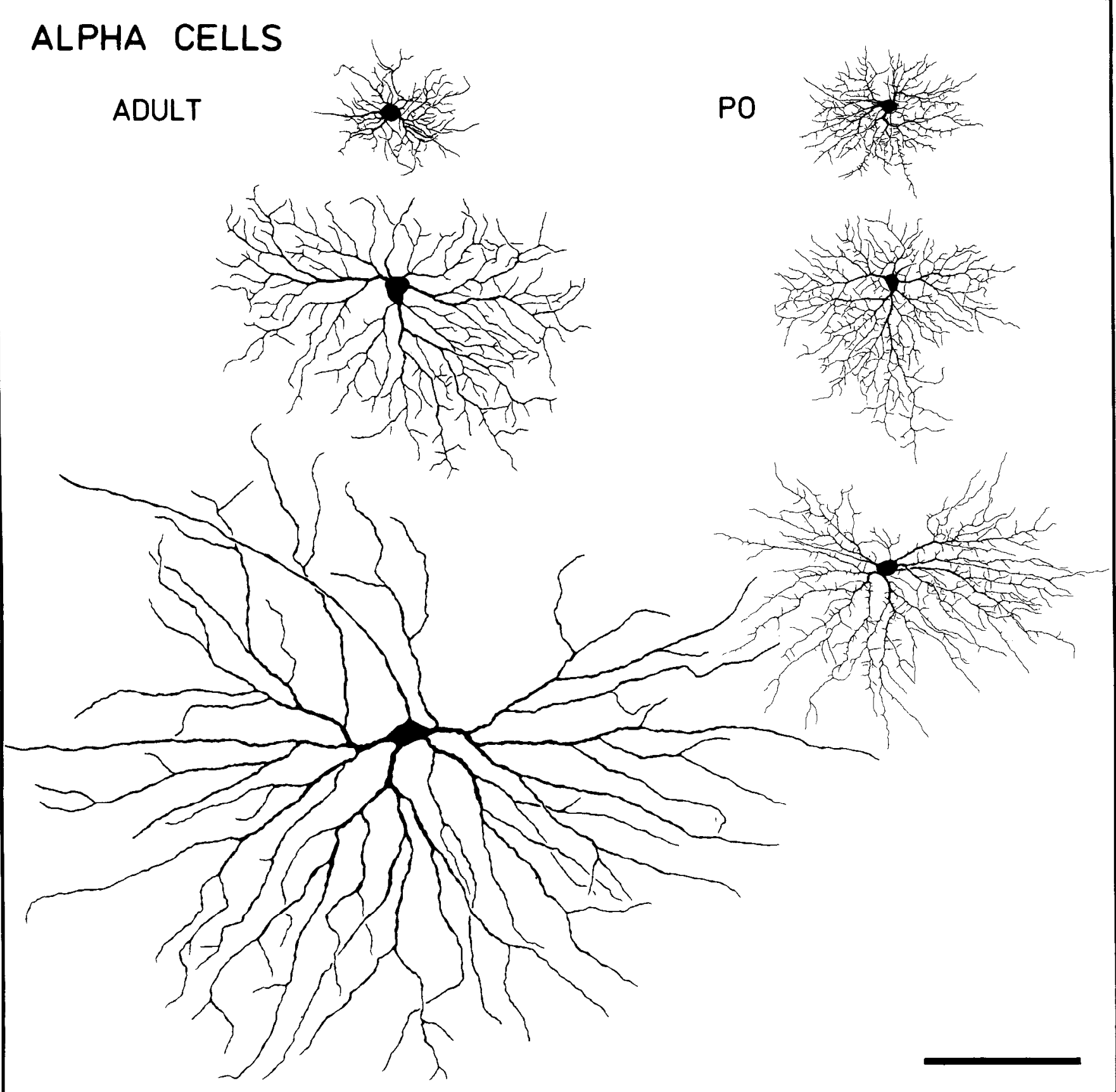

Figure 8. Comparison of $\mathrm{P} 0$ and adult alpha cells reveals that the eccentricity dependence characteristic of adult cells is present from birth. This means that cells closest to the area centralis are smaller than the same class of cell in the retinal periphery. As illustrated, the basic morphology of P0 ganglion cells resembles that of adult cells from equivalent retinal locations. The smallest cells at the top of the diagram are $0.2 \mathrm{~mm}$ (adult) and $0.3 \mathrm{~mm}(\mathrm{P} 0)$ from the area centralis. The middle cells are at an eccentricity of $2.6 \mathrm{~mm}$ (adult) and $1.7 \mathrm{~mm}$ ( $\mathrm{P} 0$ ), and the largest cells at the bottom from $7.5 \mathrm{~mm}$ (adult) and $5.8 \mathrm{~mm}(\mathrm{P} 0)$, respectively. Scale, $200 \mu \mathrm{m}$.

tral alpha cell somata continued to grow until around 3 weeks of age, when they approached adult proportions, whereas central beta cells exhibited adult dimensions from birth. It may be that the later onset of alpha cell genesis, as compared to that of beta cells (Walsh and Polley, 1985), can in part account for the protracted growth of central alpha cell somata.

The retinal region in which both alpha and beta cells exhibited the most prolific postnatal growth of soma and dendritic field was the retinal periphery. In the far periphery, at least a 3-fold increase in cell dimensions was observed. However, there was a remarkable difference in the temporal sequence of cell growth between the 2 cell types. While alpha cells approached their adult dimensions by 3 weeks of age, the size of beta cells remained unchanged until around the same age, when their major period of postnatal development began. Consistent with previous reports (Rusoff and Dubin, 1978; Rusoff, 1979), from 3 weeks of age beta cell dendritic field size increased dramatically in the far periphery (Figs. 14, 15). It has previously been ob- 


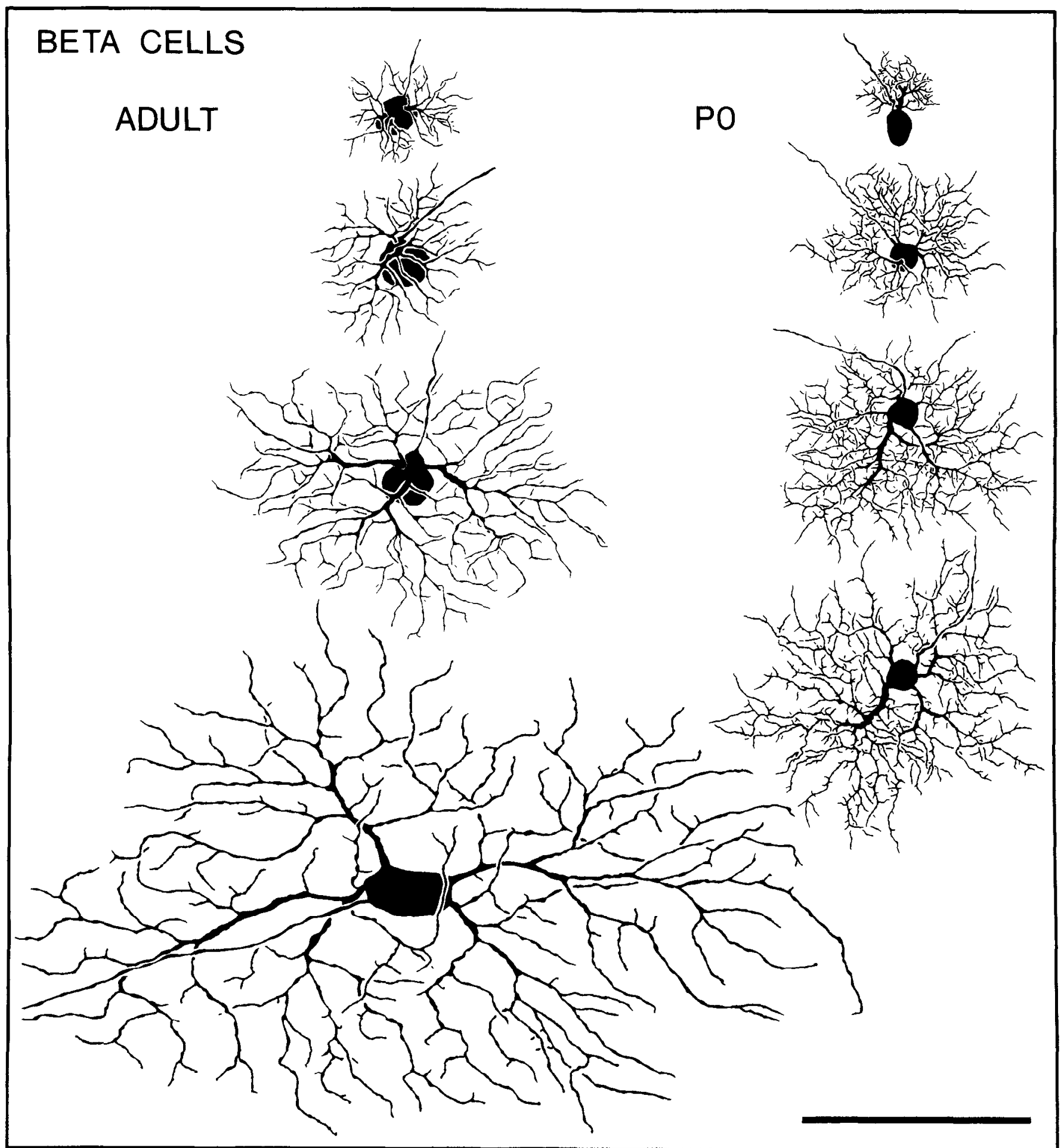

Figure 9. Comparison of P0 and adult beta cells reveals the same eccentricity dependence as in alpha cells (Fig. 8). From birth, the smallest cells shown at the top of the diagram $(0.8 \mathrm{~mm}$ eccentricity, adult; $1.1 \mathrm{~mm}, \mathrm{P} 0)$ are near the area centralis. The cells at the bottom of the diagram ( 7.7 $\mathrm{mm}$, adult; $6.0 \mathrm{~mm}, \mathrm{P} 0$ ) are in the most peripheral retina. The second smallest 2 cells (middle) are $1.7 \mathrm{~mm}$ (adult) and $1.25 \mathrm{~mm}$ (P0), respectively from the area centralis, and the remaining cells are situated more peripherally at $5.4 \mathrm{~mm}$ (adult) and $3.7 \mathrm{~mm}(\mathrm{P} 0)$, respectively. Scale, $100 \mu \mathrm{m}$.

served that dendritic fields of beta cells at 3 weeks of age require more than passive stretching to reach their adult size, since stretching could account for only $58 \%$ of this increase (Mastronarde et al., 1984). The reason for the temporal disparity in the cessation of growth of different cell types remains to be elucidated.

\section{Changes in morphology}

The current findings of devclopmental components such as spiny protuberances and dendritic "rings" as consistent early postnatal features on both alpha and beta cells are indicative of some form of restructuring that occurs within the dendrites of 

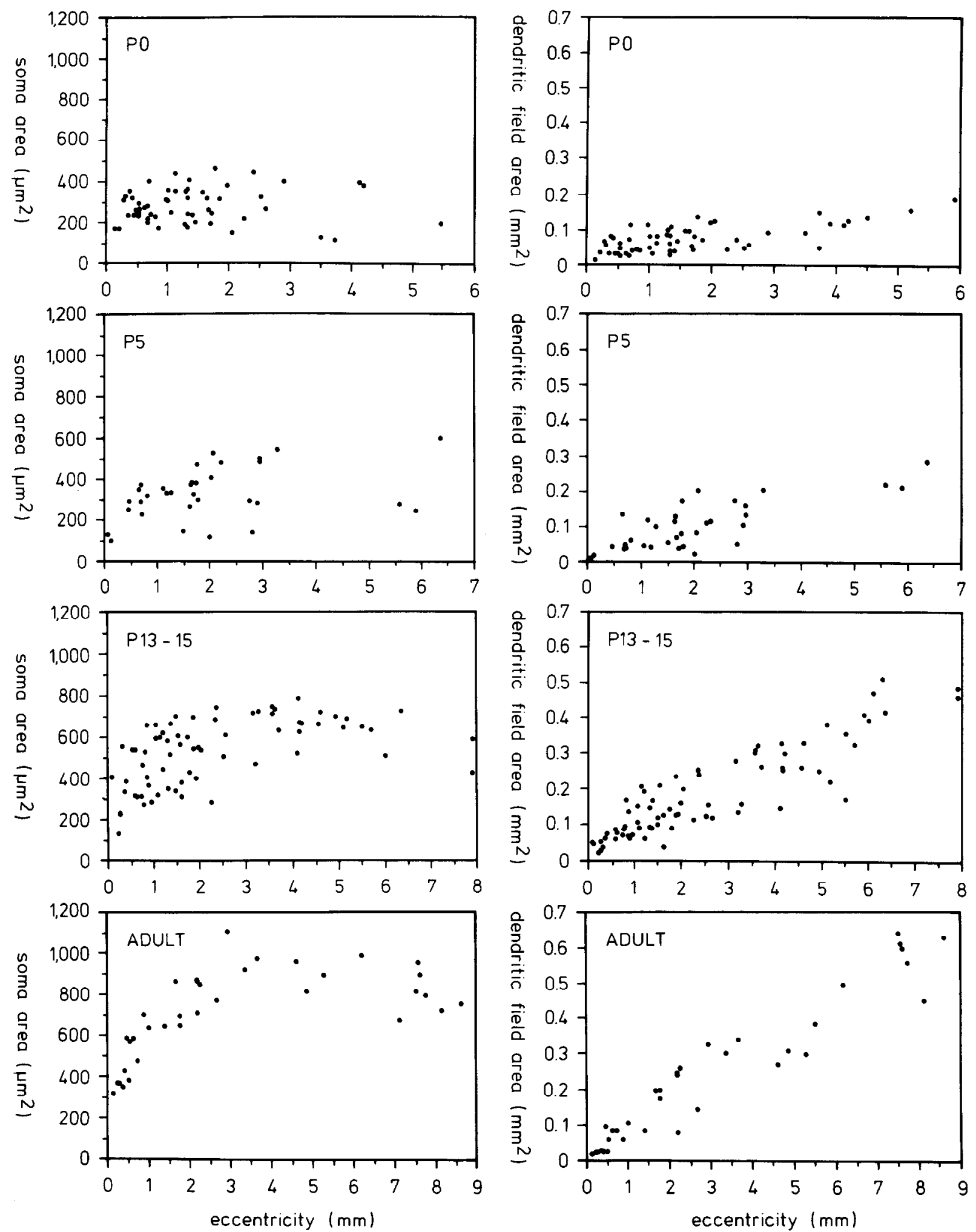

Figure 10. In the left-hand graphs, alpha cell soma area from P0 to adult is plottcd against cccentricity. The scale on the abscissa varies with age, but reflects the actual distance from the area centralis to the most peripheral retinal cells injected. The same convention applies to Figure 11 . An increase in soma size can be seen from P0 to P13-P15, when adult values were approached. In the set of graphs on the right, alpha cell dendritic field area is plotted against retinal eccentricity. In peripheral retina, there was a gradual increase in dendritic field area from P0 to adulthood. However, like soma area, dendritic field area approached adult values around P13-P15. 

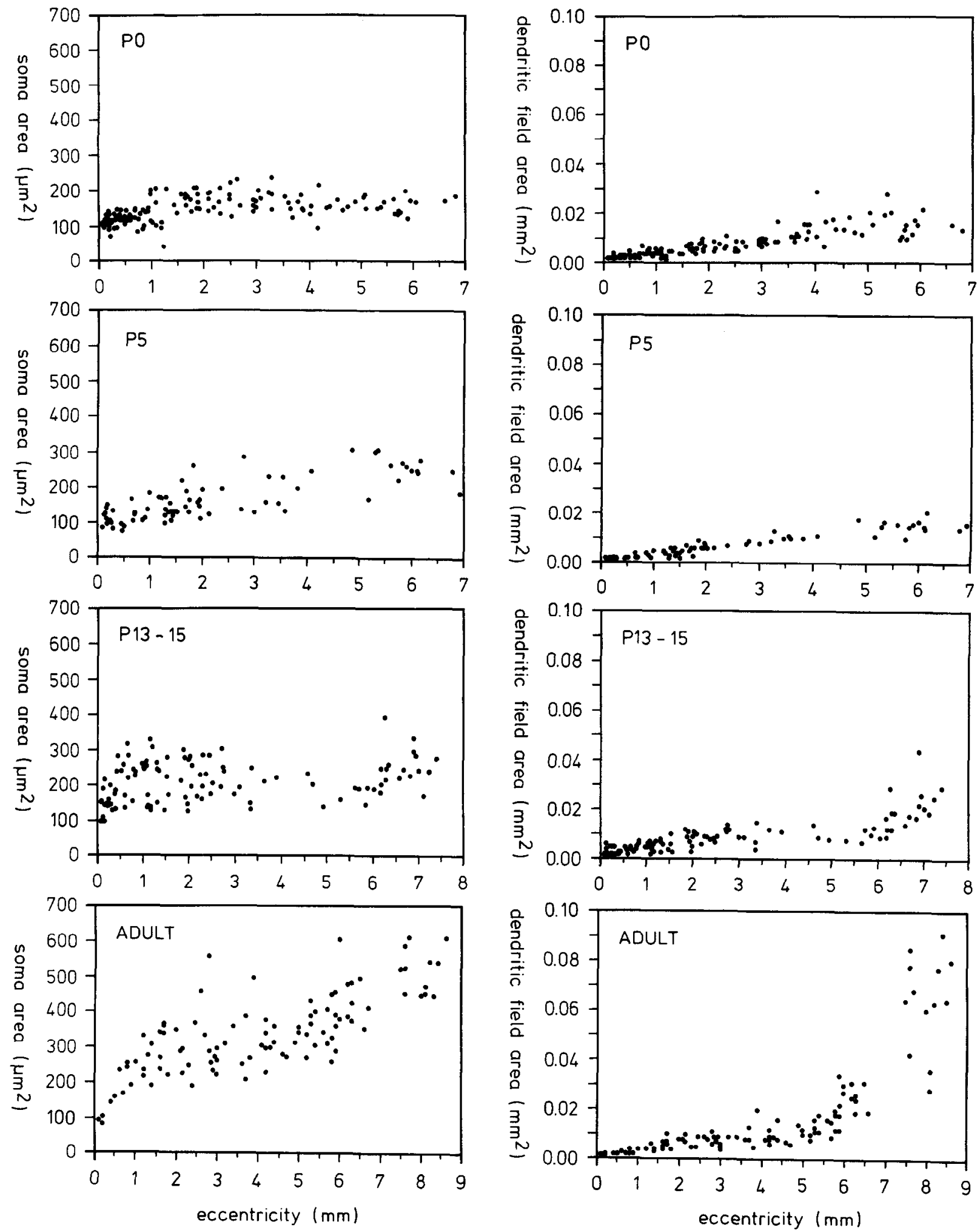

Figure 11. Soma area of beta cells is plotted against retinal eccentricity in the set of graphs to the left. In contrast to alpha cells (Fig. 10), peripheral beta cells began their major period of expansion from P13-P15 to adulthood. In the right-hand graphs, beta cell dendritic field area is plotted against retinal eccentricity. Expansion of dendritic field area of beta cells followed the same pattern of increase as soma area, with the most pronounced period of growth beginning at P13-P15. 

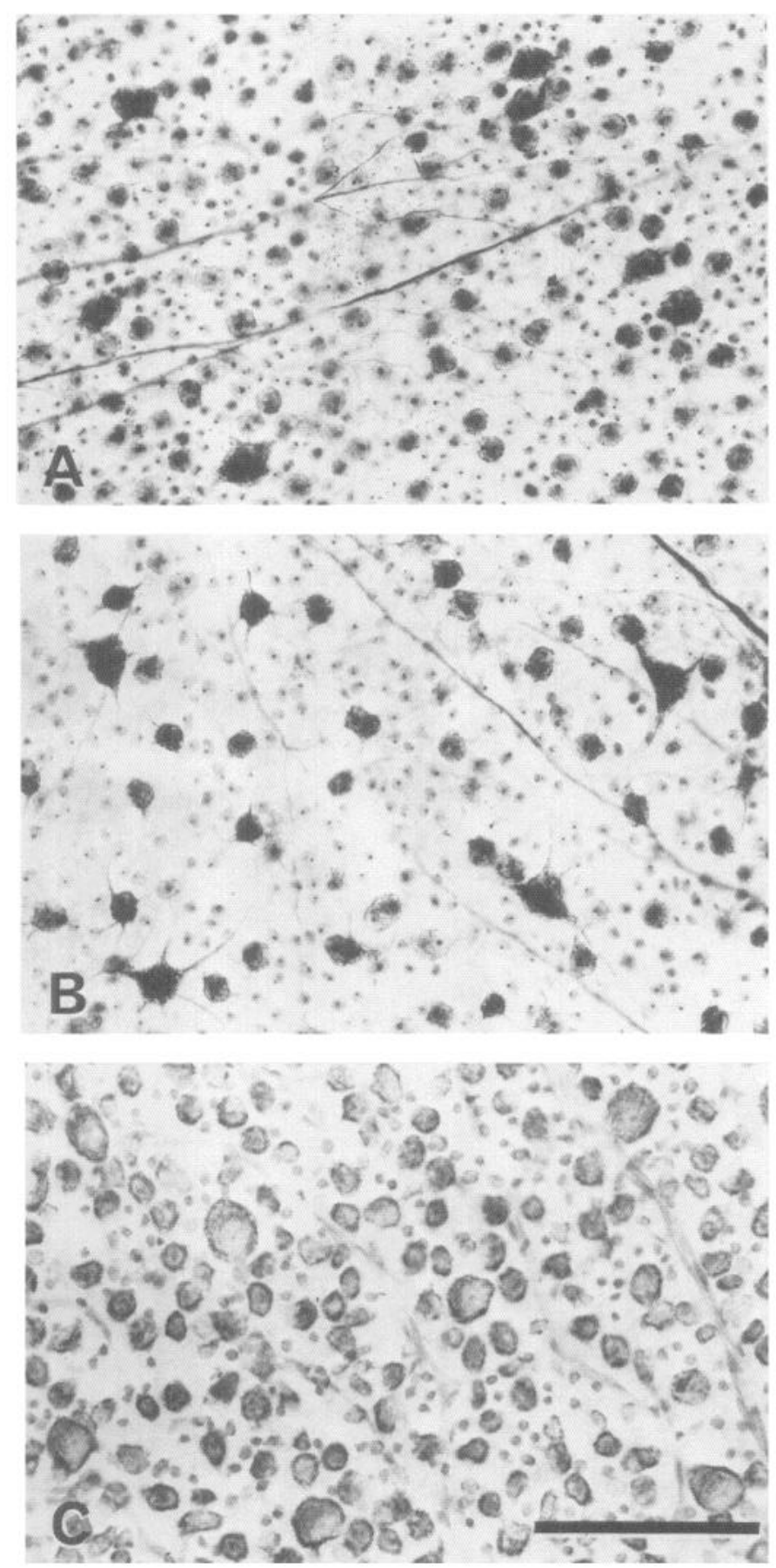

Figure 12. A, Montage of retinal ganglion cell layer of P0 kitten at 0.7 $\mathrm{mm}$ eccentricity. Seven alpha cells can be clearly distinguished in this reduced-silver preparation. $B, \mathrm{~A}$ P0 retina at $1.7 \mathrm{~mm}$ eccentricity, showing 4 alpha cells in a similar silver preparation. $C$, Cresyl violet preparation of a P15 retina at $0.9 \mathrm{~mm}$ eccentricity, which is comparable to $A$. There are 7 cells in the field that are presumed to be alpha cells. Scale, $100 \mu \mathrm{m}$.

both cell types. Spine-like structures have also been reported in embryonic material (Ramoa et al., 1987). The "rings" or lacunae found predominantly in the peripheral regions of kitten retinae resemble those described as representative features of differentiating dendrites in human cortex (Purpura, 1975) and in the central nervous system of a variety of other species (Morest, 1969a, b, 1970a). Lacunae presumably represent intradendritic organelles, which are most commonly encountered in "dendritic shafts undergoing rapid length increases" (Purpura, 1975) and, along with other features of differentiating dendrites (Morest, 1970 b), are believed to be obligatory features of normal development and not pathological phenomena (Morest, 1969b). Their presence on ganglion cell dendrites in early postnatal retinae is consistent with this concept, especially since most "rings" were detected on the dendrites of cells in peripheral retina, the region of most active postnatal growth. However, why lacunae should disappear within the first few postnatal weeks is unclear in the case of beta cells, which, unlike alpha cells, have a marked phase of dendritic growth after postnatal week 3 .

More powerful evidence of remodeling is the adjustment in the number of dendritic branching points of alpha ganglion cells, which at early postnatal ages consistently exceeded those of adults. This finding is in accord with an observation from E57 kitten retinae, where dendritic branches appeared comparable in number to, or exceeded, those of the adult (Maslim et al., 1986). The subsequent age-related reduction in nodes and tips cannot be attributed to the disappearance of spiny protrusions during maturation, because they were deliberately excluded from the counts (see Results). Their inclusion in the analysis would make the observed loss of nodes and tips during growth even more dramatic.

Concomitantly, the distance between branching points for alpha cell dendrites doubled between $\mathrm{P} 0$ and adulthood. Therefore, while alpha cell soma and dendritic field size were enlarging with age, the internal structure of the dendritic tree was remodeled by the elimination of the spiny protuberances along the dendrites and the decrease of the overall number of nodes and tips. This is illustrated in the more densely branched dendritic fields of kitten alpha cells, as compared to those of adult (Fig. 8).

\section{Stratification of dendrites}

Most alpha cells of both "on" and "off" subtypes had attained the adult pattern of dendritic unistratification within the IPL by $\mathrm{P} 0$. However, among the early postnatal alpha cells were some that had a few bistratified dendrites. These branches were most probably vestiges of a prenatal period when dendrites ramified widely, since ganglion cell dendrites have been observed to initially spread diffusely in both the ganglion cell layer and IPL during their early development (Maslim et al., 1986). These dendritic aberrations were no longer encountered on cells injected with LY between P5 and P13.

The period during which aberrant stratification was detected is approximately coincident with the segregation of dendrites into sublaminae of the IPL (Maslim et al., 1986). Concomitantly, ribbon synapses, characteristic of bipolar cells, began to form in the IPL, although conventional (probably amacrine cell) synapses were present prenatally (Cragg, 1975; Morrison, 1982; Maslim and Stone, 1986). How elimination of spiny protuberances from along the dendrites or the cessation of aberrant stratification patterns may relate to synaptogenesis remains to be clarified ultrastructurally. Nevertheless, the temporal proximity of these events is suggestive of some causal link, especially when combined with the central-to-peripheral gradient of development common to both retinal ganglion cell and bipolar cell synaptogenesis (Maslim and Stone, 1986).

In the cat retina, cone bipolar cells occur as "on"- and "off"mediating functional varieties and are presumed to regulate 

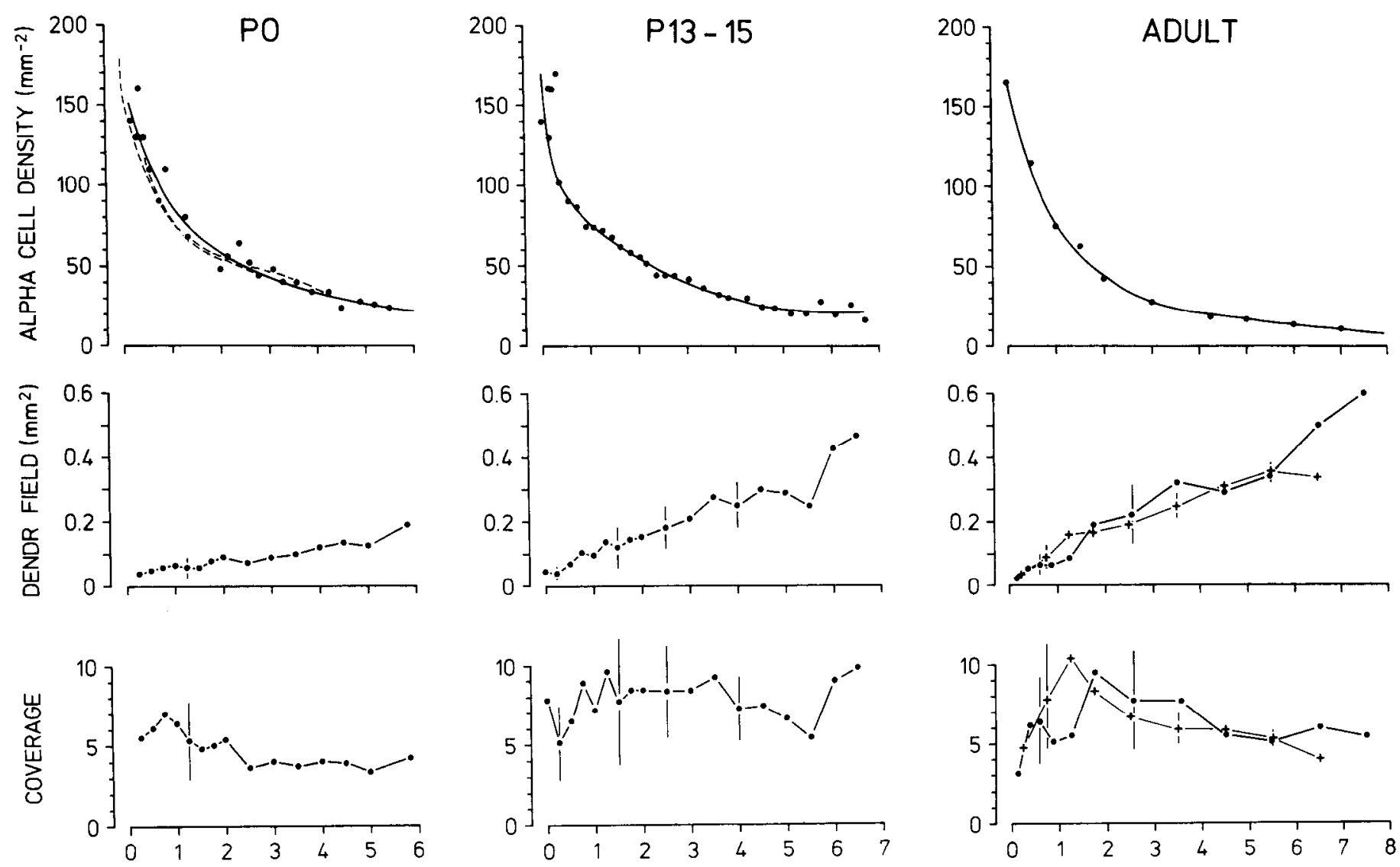

DISTANCE FROM CENTRAL AREA $(\mathrm{mm})$

Figure 13. Graphs indicate alpha cell density, dendritic field size, and coverage factor changes during maturation. Upper, In each of the 3 age stages, the diagram shows alpha cell density as a function of eccentricity, measured along the raphe line. $P 0$, Data points from a reduced-silverstained retina from which the solid curve was interpolated. To show individual variability, broken lines represent equivalent curves from the other silver-stained retina of the same animal and a cresyl violet-stained retina of another animal. P13-P15, Data points and curve of a cresyl violetstained P1S retina. Adult, Reduced-silver stain (data taken from Fig. 14B of Wässle et al., 1981c). Middle, Alpha cell dendritic field area from Lucifer yellow-filled $(\bullet)$ or silver-stained $(+)$ material. The curves give mean values $(\bullet,+)$ and, in some representative instances, standard deviations (vertical bars) extracted from Figure 10 for LY cells and from Figure 14A of Wässle et al. (1981c) for adult silver-stained cells. The 2 staining methods give comparable results in the adult. Lower, Alpha cell dendritic field overlap (coverage) calculated from cell density and dendritic field area. In all graphs, the mean values are shown and representative standard deviations are shown $( \pm 1$ SD) where the size of the sample permitted. Dendritic coverage increased from $P 0$ to $P 13-15$, after which it dropped again to the adult values. Peripheral retina experienced the greatest increase in dendritic coverage, which is consistent with this being the area of maximal dendritic field growth. Since cell density remained similar to that at P0, the increased dendritic field area of P13-15 alpha cells, which approximated the adult values, resulted in a degree of dendritic overlap that was again reduced as the retina attained its adult proportions. Because of the growth of the retina, corresponding eccentricities change from P0 to adult.

responses of "on"- and "off'-ganglion cells, respectively (Famiglietti and Kolb, 1976; Nelson et al., 1978; Sterling, 1983). Anatomically, their axonal endings in the IPL stratify in either of the 2 levels of ganglion cell dendritic arborization. The concurrence between the initial appearance of ribbon (bipolar) cell synapses and the stabilization and refinement of alpha cell dendritic stratification may indicate a recognition process between these neurons, which are later functionally cooperative in the "on" and "off" channels of retinal processing. The intriguing question remains as to which retinal elements and mechanisms determine a neuron's fate as a member of the "on" or "off" pathway.

\section{Dendritic coverage}

The estimated adult alpha cell dendritic coverage is such that the overlap of dendritic fields ensures that every retinal point is covered by the dendritic fields of at least 3 alpha cells in central retina and 6-7 cells further peripherally. Figure 13 illustrates how this adult coverage develops. From P0 to P15, the eccentricity-dependent coverage increases markedly to an overlap that is even larger than that in the adult retina. This is the result of the pronounced enlargement of dendritic field area during the first few postnatal weeks, whereas the density of alpha cells at P15 is only slightly lower than that at P0. The major area where coverage increases is the peripheral retina, the region in which the most dramatic dendritic expansion occurs. After P15 the continued areal growth of the retinal periphery is not paralleled by alpha cell dendritic growth and, consequently, coverage is reduced. This analysis is based on pooled data and therefore represents a trend. Ideally, it should be repeated by obtaining dendritic field and density data for the same individuals, which is not yet feasible. Such changes in overlap would mean that the dendrites slide with respect to one another. 

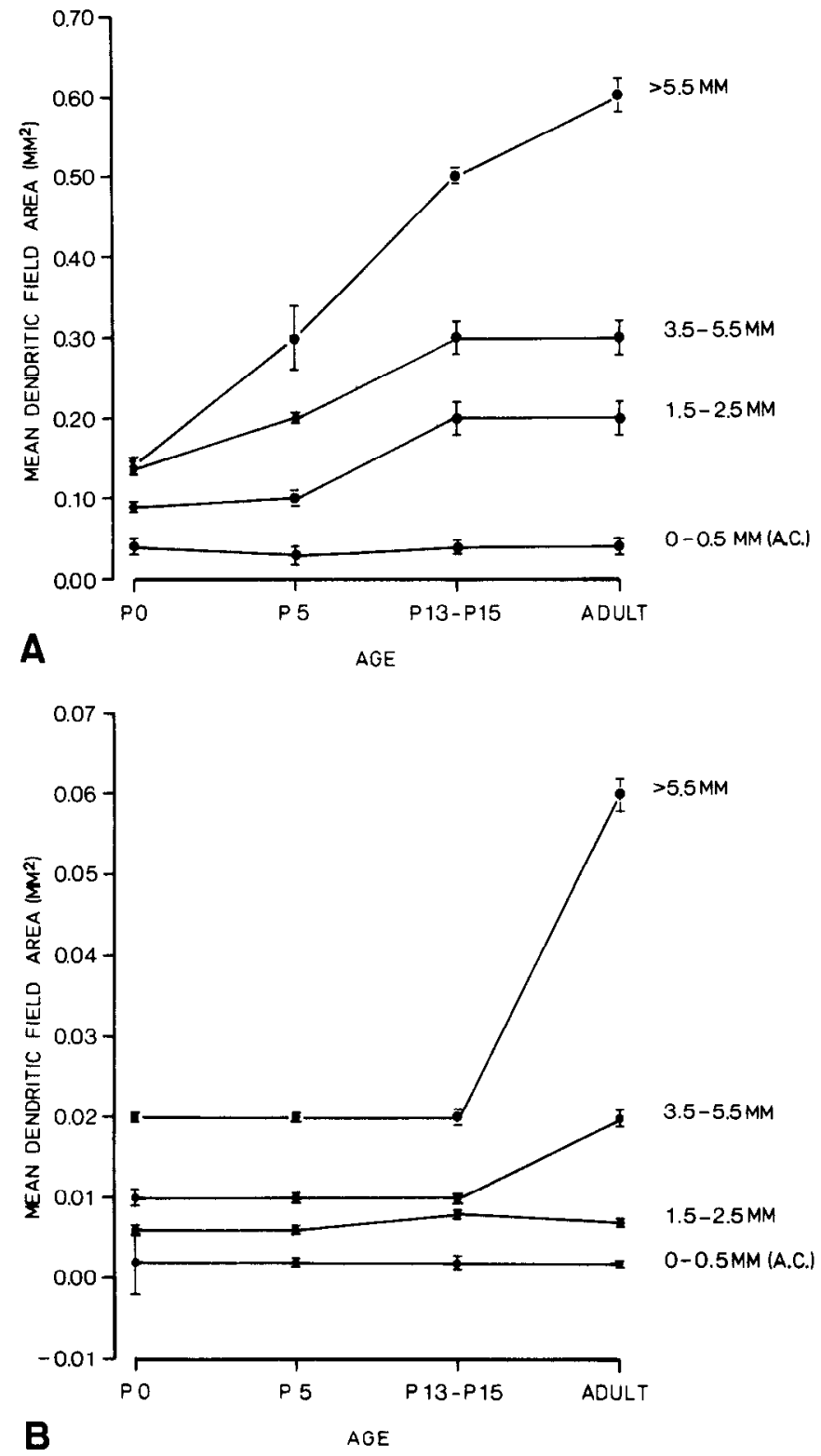

Figure 14. Average dendritic field area ( \pm 1 SEM) of alpha $(A)$ and beta $(B)$ cells plotted against age at various retinal eccentricities from the area centralis to the periphery. For alpha cells, there was a gradual increase in dendritic field area with increasing eccentricity, consistent with the tendency for peripheral cells to have larger dendritic fields than central cells. In addition, there was a tendency for peripheral alpha cell size 10 increase with age. Beta cells displayed the same eccentricity dependence as alpha cells. However, it was not until P13-P15 that peripheral beta cells showed a marked enlargement of their dendritic field area, which continued to expand until the adult values were reached.

\section{References}

Boycott, B. B., and H. Wässle (1974) The morphological types of ganglion cells of the domestic cat's retina. J. Physiol. (Lond.) 240: 397-419.

Cleland, B. G., W. R. Levick, and H. Wässle (1975) Physiological identification of a morphological class of cat retinal ganglion cells. J. Physiol. (Lond.) 248: 151-171.

Cragg, B. G. (1975) The development of synapses in the visual system of the cat. J. Comp. Neurol. 160: 147-166.

Dann, J. F., E. H. Buhl, and L. Peichl (1986) Development of kitten

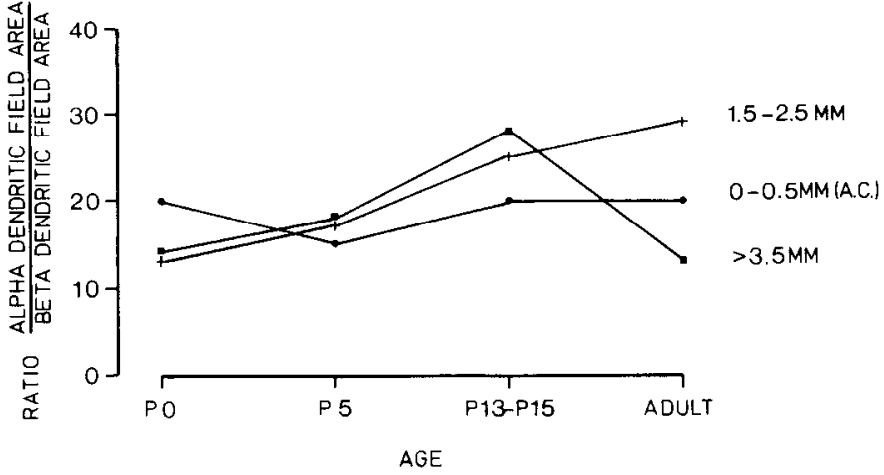

Figure 15. The difference between the pattern of dendritic field enlargement of alpha and beta cells is clearly illustrated by the graph of the ratio of alpha to beta dendritic field area as a function of age and eccentricity. There was little variation of this ratio in central retina (0) or in the near periphery $(+)$. However, further peripherally $(\square)$, the ratio declined from P13-P15, with a steep reduction in the far periphery by adulthood. The onset of this variation in the dendritic field ratio is commensurate with the period when beta cell dendritic fields began their major period of expansion, a time when alpha cells approached their adult proportions.

retinal ganglion cells: A morphological and quantitative analysis. Neurosci. Lett. (Suppl.) 26: 426.

Dann, J. F., E. H. Buhl, and L. Peichl (1987) Dendritic maturation in cat retinal ganglion cells: A Lucifer Yellow study. Neurosci. Lett. 80: 21-26.

Enroth-Cugell, C., and J. G. Robson (1966) The contrast sensitivity of retinal ganglion cells of the cat. J. Physiol. (Lond.) 197: 517-552.

Famiglietti, E. V., and H. Kolb (1976) Structural basis for "on"- and "off"-center responses in retinal ganglion cells. Science 194: 193-195.

Illing, R. B., and H. Wässle (1981) The retinal projection to the thalamus in the cat: A quantitative investigation and a comparison with the retinotectal pathway. J. Comp. Neurol. 202: 265-285.

Johns, P. R., A. C. Rusoff, and M. W. Dubin (1979) Postnatal neurogenesis in the kitten retina. J. Comp. Neurol. 187: 545-556.

Kelly, J. P., and C. D. Gilbert (1975) The projection of different morphological types of ganglion cells in the cat retina. J. Comp. Neurol. 163: 65-80.

Levick, W. R. (1975) Form and function of cat retinal ganglion cells. Nature 254: 659-662.

Levick, W. R., and L. N. Thibos (1983) Receptive fields of cat ganglion cells: Classification and construction. Prog. Retinal Res. 2: 267-319.

Maslim, J., and J. Stone (1986) Synaptogenesis in the retina of the cat. Brain Res. 373: 35-48.

Maslim, J., M. Webster, and J. Stone (1986) Stages in the structural differentiation of retinal ganglion cells. J. Comp. Neurol. 254: 382402.

Mastronarde, D. N., M. A. Thibeault, and M. W. Dubin (1984) Nonuniform postnatal growth of the cat retina. J. Comp. Neurol. 228: 598-608.

Morest, D. K. (1969a) The differentiation of cerebral dendrites: A study of the post-migratory neuroblast in the medial nucleus of the trapezoid body. Z. Anat. Entwick.-Gesch. 128: 271-289.

Morest, D. K. (1969b) The growth of dendrites in the mammalian brain. Z. Anat. Entwick.-Gesch. 128: 290-317.

Morest, D. K. (1970a) A study of neurogenesis in the forebrain of opossum pouch young. Z. Anat. Entwick.-Gesch. 130: 265-305.

Morest, D. K. (1970b) The pattern of neurogenesis in the retina of the rat. Z. Anat. Entwick.-Gesch. 131: 45-67.

Morrison, J. D. (1982) Postnatal development of the area centralis of the kitten retina: An electron microscopic study. J. Anat. 135: 255271.

Nelson, R., E. V. Famiglietti, and H. Kolb (1978) Intracellular staining reveals different levels of stratification for on- and off-centre ganglion cells in cat retina. J. Neurophysiol. 41: 472-483.

Peichl, L., and H. Wässle (1981) Morphological identification of onand off-centre brisk transient (Y) cells in the cat retina. Proc. R. Soc. Lond. [Biol.] 212: 139-156. 
Percheron, G. (1979) Quantitative analysis of dendritic branching. I. Simple formulae for the quantitative analysis of dendritic branching. Neurosci. Lett. 14: 287-293.

Purpura, D. P. (1975) Dendritic differentiation in human cerebral cortex: Normal and aberrant developmental patterns. In Advances in Neurology, vol. 12, G. W. Kreutzberg, ed., pp. 91-116, Raven, New York.

Ramoa, A. S., G. Campbell, and C. J. Shatz (1987) Transient morphological features of identified ganglion cells in living fetal and neonatal retina. Science 237: 522-525.

Rapaport, D. H., and J. Stone (1983) The topography of cytogenesis in the developing retina of the cat. J. Neurosci. 3: 1824-1834.

Rodieck, R. W. (1979) Visual pathways. Annu. Rev. Neurosci. 2: 193225

Rusoff, A. C. (1979) Development of ganglion cells in the retina of the cat. In Developmental Neurobiology of Vision, vol. 27, R. D. Freeman, ed., pp. 19-29, Nato Advanced Study Institute, New York.

Rusoff, A. C., and M. W. Dubin (1978) Kitten ganglion cells: Dendritic ficld size at 3 weeks of age and correlation with receptive field size. Invest. Ophthalmol. Vis. Sci. 17: 819-821.

Saito, H.-A. (1983) Morphology of physiologically identified X-, Y-, and W-type retinal ganglion cells of the cat. J. Comp. Neurol. 221: 279-288.

Shatz, C. J., and D. W. Sretavan (1986) Interactions between retinal ganglion cells during the development of the mammalian visual system. Annu. Rev. Neurosci. 9: 171-207.

Sterling, P. (1983) Microcircuitry of the cat retina. Annu. Rev. Neurosci. 6: 149-185.

Stewart, W. W. (1981) Lucifer dyes-highly fluorescent dyes for biological tracing. Nature 292: 17-21.
Stone, J., and K. P. Hoffmann (1972) Very slow-conducting ganglion cells in the cat's retina: A major, new functional type? Brain Res. 43. 610-616.

Stone, J., D. H. Rapaport, R. W. Williams, and L. Chalupa (1982) Uniformity of cell distribution in the ganglion cell layer of prenatal cat retina: Implications for mechanisms of retinal development. Dev. Brain Res. 2: 231-242.

Tauchi, M., and R. H. Masland (1984) The shape and arrangement of the cholinergic neurones in the rabbit retina. Proc. R. Soc. Lond. [Biol.] 223: 101-119.

Voigt, T. (1986) Cholinergic amacrine cells in the rat retina. J. Comp. Neurol. 248: 19-35.

Walsh, C., and E. H. Polley (1985) The topography of ganglion cell production in the cat's retina. J. Neurosci. 5: 741-750.

Wässle, H., and R. B. Illing (1980) The retinal projection to the superior colliculus in the cat: A quantitative study with HRP. J. Comp. Neurol. 190: 333-356.

Wässle, H., and H. J. Riemann (1978) The mosaic of nerve cells in the mammalian retina. Proc. R. Soc. Lond. [Biol.] 200: 441-461.

Wässle, H., B. B. Boycott, and R. B. Illing (1981a) Morphology and mosaic of on- and off-beta cells in the cat retina and some functional considerations. Proc. R. Soc. Lond. [Biol.] 212: 177-195.

Wässle, H., L. Peichl, and B. B. Boycott (1981b) Dendritic territories of cat retinal ganglion cells. Nature 292: 344-345.

Wässle, H., L. Peichl, and B. B. Boycott (1981c) Morphology and topography of on- and off-alpha cells in cat retina. Proc. R. Soc. Lond. [Biol.] 212: 157-175. 